\title{
PENGARUH KOMPENSASI DAN MOTIVASI KERJA TERHADAP KINERJA PEGAWAI PADA PT TUNAS DWIPA MATRA CABANG PRAMUKA BANDAR LAMPUNG
}

\author{
Kinanti Nurul Faithya ${ }^{(1)^{*}}$, Fahrizi ${ }^{(2)}$ \\ Fakultas Ekonomi Universitas Sang Bumi Ruwa Jurai \\ *email: kinantinurulf.31023@gmail.com,fahrizi@gmail.com
}

\begin{abstract}
Abstrak. Upaya peningkatan kinerja pegawai dapat dilakukan dengan memberikan kompensasi dan meningkatkan motivasi. Ini dapat mengarah pada upaya dan mengoptimalkan kinerja. Tujuan penelitian adalah untuk mengetahui pengaruh kompensasi dan motivasi kerja terhadap kinerja karyawan pada PT Tunas Dwipa Matra Pramuka Cabang Bandar Lampung. Metode yang digunakan adalah pendekatan deskriptif asosiatif. Populasi dalam penelitian ini adalah seluruh pegawai PT Tunas Dwipa Matra Cabang Pramuka yang terdiri dari pegawai administrasi, loket penjualan, pemasaran dan mekanik yang berjumlah 228 orang. Teknik pengambilan sampel menggunakan Simple Random Sampling sebanyak 57 responden. Hasil penelitian menunjukkan gambaran kompensasi (X1) karyawan diketahui bahwa konsep diri karyawan baik dengan pencapaian 70,8\%. Motivasi kerja (X2) secara umum sudah baik terutama pada indikator keterampilan dengan rata-rata pencapaian $67,4 \%$. Kinerja karyawan yang paling menonjol adalah kolaborasi dengan pencapaian $66 \%$. Hasil uji hipotesis menyimpulkan terdapat pengaruh positif kompensasi (X1) dan motivasi kerja (X2) terhadap kinerja karyawan PT Tunas Dwipa Matra Cabang Pramuka Bandar Lampung, baik secara parsial maupun simultan. Untuk meningkatkan kinerja dapat dilakukan dengan meningkatkan kompensasi motivasi kerja karyawan. Penelitian ini merekomendasikan agar PT Tunas Dwipa Matra meningkatkan pengetahuan karyawan, meningkatkan kinerja secara maksimal
\end{abstract}

Kata kunci: Kompensasi, motivasi kerja dan kinerja

\begin{abstract}
Abstrak.The efforts to improve employee performance can be taken by providing compensation and increasing motivation. It can lead to efforts and optimizing performance. The purpose of study is determining the effect of compensation and work motivation on employee performance at PT Tunas Dwipa Matra Pramuka Branch in Bandar Lampung.The method use an associative descriptive approach. The population are all employees of PT Tunas Dwipa Matra Pramuka Branch consisting of administrative employees, sales counters, marketing and mechanics which totaled 228. The sampling technique use Simple Random Sampling as many as 57 respondents. The results showed a description of compensation (X1) of employees known that the employee's self-concept was good with $70.8 \%$ achievement. Work motivation (X2) in general is already good, especially on the indicator of skills with an average achievement of 67.4\%. The most outstanding employee performance is collaboration with $66 \%$ achievement. Hypothesis test results conclude there is a positive effect of compensation (X1) and work motivation (X2) on the performance of employees of PT Tunas Dwipa Matra Pramuka Branch in Bandar Lampung, both partially and simultaneously. To improve performance can be done by increasing employee work motivation compensation. This study recommends that PT Tunas Dwipa Matra increase employee knowledge, improve performance to the fullest.
\end{abstract}

Keywords: Compensation, work motivation and performance

\section{PENDAHULUAN}

Sumber daya
bagian penting
e-ISSN : 2722-0117
p-ISSN : 2715-1018

perkembangan perusahaan dan merupakan pusat kekuatan yang dapat menggerakkan dinamika perusahaan. Sebagaimana 
pendapat Hasibuan (2005:78) bahwa semakin besar perusahaan maka masalah sumber daya manusia akan semakin besar dan kompleks. Sehingga perusahaan perlu memberikan perhatian secara maksimal kepada pegawai, khususnya perhatian pada tingkat kesejahteraannya, dengan demikian diharapkan pegawai bersangkutan dapat terdorong untuk memberikan segala kemampuan sesuai dengan yang dibutuhkan perusahaan.

Permasalahan yang berkaitan dengan sumber daya manusia dalam suatu perusahaan menuntut untuk diperhatikan, karena sebesar apapun modal perusahaan yang dimiliki, maka pegawai yang pada akhirnya akan menjalankannya. Sebagaimana menurut Umar (2004:11) bahwa tanpa didukung dengan kualitas yang baik dari pegawai dalam melaksanakan tugasnya maka keberhasilan perusahaan tidak akan tercapai. Kontribusi pegawai pada suatu perusahaan akan menentukan maju ataupun mundurnya perusahaan.

Sehingga perusahaan yang ingin maju harus dapat memperhatikan sumber daya manusia sebagai pegawai yang ada pada perusahaan tersebut. Sejalan yang dikemukakan oleh Siagian (2008:22), bahwa perusahaan yang ingin maju dan berkembang akan memikirkan kinerja para pegawainya, dengan kinerja yang didapat oleh pegawai akan menimbulkan semangat pegawai untuk bekerja lebih baik lagi. Namun bila pegawai dalam suatu perusahaan tidak mendapatkan penghargaan atas kinerja yang dilakukan, maka mereka cenderung akan mencari perusahaan lain yang mampu memberikan kinerja ataupun melakukan tindakantindakan untuk meminta perhatian pada perusahaan agar memikirkan kinerja pegawai. Kinerja pegawai yang belum optimal, dapat diketahui dari tidak tercapainya target pencapaian pekerjaan pegawai dan rendahnya produktivitas pegawai dalam menyelesaikan pekerjaan.

Kinerja seseorang pada dasarnya sebagaimana pendapat Siagian (2008:66), merupakan hal yang bersifat individual. Setiap individu akan memiliki tingkat kinerja yang berbeda-beda sesuai dengan sistem nilai-nilai yang berlaku pada dirinya. Hal tersebut disebabkan karena adanya perbedaan pada masing-masing individu, semakin banyak aspek-aspek dalam pekerjaan yang sesuai dengan keinginan individu tersebut maka semakin tinggi tingkat kinerja yang dirasakan dan sebaliknya.

Untuk mendukung kinerja pegawai maka manajemen perusahaan harus menjalankan fungsinya dengan baik dalam mengatur dan mengarahkan pegawai untuk dapat menjalankan tugas sesuai dengan fungsi dan tujuan perusahaan. Menurut Hasibuan (2005:78), bahwa perspektif ilmu manajemen sumber daya manusia menggariskan bahwa salah satu upaya yang dapat ditempuh perusahaan adalah dengan melakukan pengaturan, pengarahan, dan pendayagunaan sumber daya manusia sehingga dapat mengoptimalkan kinerja mereka bagi perusahaan. Kinerja pada dasarnya merupakan tingkat keberhasilan seseorang atau kelompok orang dalam melaksanakan tugas dan tanggung jawabnya serta kemampuan untuk mencapai tujuan dan standar yang telah ditetapkan.

Kinerjamerefleksikan kesuksesan suat $\mathrm{u}$ perusahaan, maka dipandang penting untuk mengukur karakteristik tenaga kerjanya. Menurut Hasibuan (2005:176),1 menyatakan kinerja merupakan kulminasi dari tiga elemen yang saling berkaitan yakni keterampilan, upaya sifat keadaan dan kondisi eksternal. Tingkat keterampilan merupakan bahan mentah yang dibawa seseorang ke tempat kerja seperti pengalaman, kemampuan, kecakapan antar pribadi serta kecakapan teknik.

Upaya untuk meningkatkan kinerja pegawai dapat ditempuh perusahaan dengan memberikan kompensasi yang sesuai dengan beban kerja pegawai. Kompensasi sebagaimana pendapat Hasibuan (2005:35), merupakan imbalan 
yang diberikan perusahaan kepada pegawainya atas pengorbanan yang diberikan kepada perusahaan. Adanya kompensasi dari perusahaan akan membuat pegawai merasa bahwa keberadaannya diakui dan dihargai oleh perusahaan, sebab pegawai merupakan sumber daya manusia potensial yang turut menentukan keberhasilan perusahaan dalam mencapai tujuannya.

Kompensasi yang dapat ditempuh perusahaan dalam meningkatkan kinerja pegawainya yaitu dapat dilakukan baik secara moril ataupun materiil. Sebagaimana pendapat Wibowo (2011:349), yang menyatakan bahwa kompensasi adalah terdiri dari kompensasi langsung dan kompensasi tidak langsung, yaitu kompensasi langsung diberikan dalam bentuk upah atau gaji, sementara itu kompensasi tidak langsung diberikan dalam bentuk tunjangan, jaminan keamanan dan kesehatan. PT Tunas Dwipa Matra Cabang Pramuka menyadari pentingnya pemberian kompensasi terhadap peningkatan kinerja, oleh karenanya kebijakan tersebut sudah berlaku menjadi kebijakan manajemen. Akan tetapi, implementasi dari kebijakan kompensasi menghasilkan respon yang beragam antara satu pegawai dengan pegawai lain karena meskipun kompensasi sudah tertulis dalam kebijakan perusahaan tetapi implementasinya masih terhambat oleh situasi dan kondisi yang berbeda. Pegawai masih merasa implementasi dari pendistribusian kompensasi belum merata karena penilaiaannya masih relatif subjektif berdasarkan kedekatan personal. Ketidakpuasan dari kebijakan kompensasi ini pada akhirnya akan memberikan efek terhadap kinerjanya secara umum.

Faktor lain yang juga diduga mempengaruhi kinerja pegawai adalah motivasi yang dapat menumbuhkan semangat kerja pegawai. Sebagaimana pendapat Handoko (2012:23) bahwa motivasi kerja berkaitan dengan sasaran manajemen sumber daya manusia yang pada dasarnya tercapainya kepuasan kerja pegawai dalam memenuhi kebutuhannya sehingga akan timbul semangat untuk memberikan hasil kerja yang lebih baik lagi. Pemenuhan kebutuhan ini disebut sebagai motivasi yang dapat mengakibatkan adanya usaha dan merupakan proses keterkaitan erat antara usaha dan pemuasan kebutuhan tertentu.

Seorang pegawai yang telah terpenuhi kebutuhan dasarnya maka ia akan memikirkan kebutuhan yang selanjutnya. Sebagaimana Siagian (2004:137), yang mengutip teori Maslow bahwa setiap individu memiliki kebutuhan yang tersusun secara hirarki dari tingkat yang paling dasar sampai pada tingkatan yang paling tinggi. Setiap kali tingkatan dasar telah terpenuhi akan muncul kebutuhan lain yang lebih tinggi, sehingga kebutuhan seseorang merupakan motivasi orang tersebut untuk melakukan sesuatu. Kebutuhan pegawai yang bekerja pada suatu perusahaan terbentuk secara beragam karena latar belakang yang beragam pula. Sangat penting bagi perusahaan untuk menjadikan kebutuhan pegawai sebagai salah satu cara untuk mencapai kinerja yang optimal. Tata lima tingkatan motivasi secara hierarkis menurut Maslow yang dikutip Siagian (2004:138) adalah: kebutuhan fisiologi, kebutuhan akan keselamatan, kebutuhan rasa memiliki dan rasa cinta, kebutuhan akan harga diri dan kebutuhan akan perwujudan diri.

Motivasi dapat diartikan sebagai keinginan untuk mencapai tingkat yang lebih tinggi terhadap tujuan perusahaan. Menurut Siswanto (2006:243), bahwa motivasi yang terbentuk dari kesungguhan dapat memuaskan kebutuhan individual. Maknanya adalah motivasi dapat timbul dari adanya kebutuhan individual yang dapat menggerakkan seseorang melakukan sesuatu dan hal itulah yang disebut dengan gairah dan motivasi kerja. Iklim kerja di PT Tunas Dwipa Matra Cabang Pramuka terindikasi belum dapat membentuk tumbuhnya motivasi bagi pegawai. Indikasi motivasi dapat dilihat dari semangat kerja atau kedisiplinan kerja. 
Masih ditemukan pegawai yang kurang disiplin misalnya tidak masuk kerja, terlambat dan pulang sebelum waktu kerja berakhir. Kondisi ini menunjukkan pegawai bekerja dengan motivasi yang rendah.

Mendapati fakta di atas, maka untuk mendukung tercapainya visi dan misi perusahaan, maka perlu sekiranya perusahaan memperhatikan hal-hal yang mendasari sebagai kebutuhan pegawai, begitu halnya yang harus dilakukan oleh PT Tunas Dwipa Matra Cabang Pramuka, sehingga pegawai dapat merefleksikan tugas pokok dan fungsinya sebagaimana yang telah menjadi ketetapan kerja. Faktanya kinerja pegawai PT Tunas Dwipa Matra Cabang Pramuka mengalami fluktuasi kondisi ini berimplikasi pada kinerja perusahaan. Permasalahan yang terjadi pada PT Tunas Dwipa Matra Cabang Pramuka bahwa pencapaian hasil kerja terbilang belum optimal. Hal tersebut dapat dilihat dari hasil kerja pegawai yang cenderung menurun tiga tahun terakhir yaitu pada tahun 2016-2018.

Pada tabel di atas, maka diketahui bahwa masih adanya permasalahan yang terjadi pada PT Tunas Dwipa Matra Cabang Pramuka yaitu belum tercapainya target kerja perusahaan, terlihat dari tingkat pencapaian target dan realisasi capaian yang diperoleh sepanjang tiga tahun terakhir yaitu tahun 2016-2018 secara keseluruhan capaian target masih fluktuatif dan cenderung menurun. Pada tahun 2016 realisasi capaian target hanya sebesar $68,0 \%$ jauh dari $100 \%$ target, tahun 2017 realisasi target menjadi 71,4\% sekalipun meningkat namun tetap jauh dari 100\% target, dan pada tahun 2018 realisasi capaian kembali menurun menjadi $66,3 \%$ masih belum mencapai $100 \%$ target. Belum tercapainya ketetapan target maka dapat dikatakan kinerja pegawai belum dilaksanakan secara optimal.

Menurunya kinerja pegawai dapat diduga berhubungan dengan motivasi kerja pegawai PT Tunas Dwipa Matra Cabang Pramuka Bandar Lampung yang belum optimal, hal tersebut dapat diketahui dari adanya tingkat kehadiran pegawai yang masih rendah.

PT Tunas Dwipa Matra Cabang Pramuka belum sepenuhnya mencapai target kehadiran yang telah ditetapkan, yaitu tingkat kehadiran pegawai hanya mencapai $81,2 \%$ dari $100 \%$ target kehadiran yang ditetapkan. Selain itu ditambah dengan adanya pegawai yang cenderung bermalasan dalam mengerjakan tugas, penyelesaian pekerjaan cenderung tidak selesai tepat waktu dan jumlah target yang ditentukan. Serta rendahnya motivasi pegawai didasari pada jarangnya pegawai diikutsertakan dalam kegiatan-kegiatan kantor dengan demikian pegawai merasa terabaikan, kurang harmonisnya komunikasi antar pegawai dan pimpinan, serta kurang adanya kewenangan dalam pengambilan tindakan kerja.

Selain itu, kompensasi yang diberikan perusahaan juga terbilang belum optimal, karena tidak adanya pemberian tunjangan yang didasarkan pada hasil kerja pegawai berdasarkan jumlah target hasil kerja yang dapat diselesaikan pegawai, artinya besaran nomimal yang diterima setiap pegawai tetap sama, meskipun terdapat perbedaan jumlah beban kerja yang dapat diselesaikan oleh pegawai. Tujuan penelitian ini adalah mengetahui pengaruh kompensasi dan motivasi kerja terhadap kinerja Pegawai pada PT Tunas Dwipa Matra Cabang Pramuka Bandar Lampung

Kompensasi adalah segala sesuatu yang diterima oleh pegawai sebagai balas jasa untuk kerja mereka. Kompensasi kerja merujuk pada semua bentuk upah atau imbalan yang berlaku bagi dan muncul dari pekerjaan mereka, dan mempunyai dua komponen yaitu ada pembayaran keuangan langsung dalam bentuk upah, gaji, insentif, komisi, dan bonus, dan ada pembayaran tidak langsung dalam bentuk tunjangan keuangan seperti asuransi dan uang liburan (Tohardi, 2007:88).

Menurut Hasibuan (2005:35), bahwa kompensasi adalah fungsi manajemen 
sumber daya manusia yang berkaitan dengan semua bentuk penghargaan yang dijanjikan akan diterima pegawai sebagai imbalan dari pelaksanaan tugas dalam upaya pencapaian tujuan perusahaan. Kompensasi

atau imbalan merupakan semua bentuk pembayaran yang diberikan oleh organisasi/perusahaan kepada pegawai sebagai balas jasa atas pelaksanaan tugas atau kontribusi pegawai kepada organisasi, baik yang diberikan secara teratur maupun situasional. Sehingga dapat diartikan bahwa fungsi kompensasi dapat diartikan sebagai pemberian penghargaan yang adil dan layak terhadap para pegawai sesuai dengan sumbangan mereka untuk mencapai tujuan.

Menurut Handoko (2012:167), keadilan eksternal merujuk kepada adanya kesesuaian imbalan yang diterima pegawai pada suatu perusahaan dengan pegawai pada perusahaan lain untuk jenis pekerjaan yang sama. Untuk mencapai keadilan eksternal tersebut perusahaan dapat menggunakan data upah dari benchmark atau melaksanakan survey pasar pada jenis pekerjaan dan ukuran perusahaan yang relatif sama untuk menentukan kebijakan upah). Kebijakan tingkat imbalan eksternal dipengaruhi oleh tingkat permintaan dan suplai tenaga kerja, pasar produk, karakteristik industri, kemampuan untuk memberikan gaji. Menurut Wibowo (2011: 348-349), pada dasarnya kompensasi adalah terdiri dari:

1. Kompensasi langsung

Kompensasi langsung merupakan kompensasi yang diberikan dalam bentuk upah/gaji sesuai dengan kontribusi yang diberikan pegawai kepada organisasi

2. Kompensasi tidak langsung

Kompensasi langsung merupakan kompensasi yang diberikan dalam bentuk tunjangan, jaminan keamanan dan kesehatan.

\section{Motivasi Kerja}

Menurut Siswanto (2006:243), motivasi diartikan sebagai keadaan kejiwaan dan sikap mental manusia yang memberikan energi, mendorong kegiatan atau moves dan mengarah atau menyalurkan perilaku ke arah mencapai kebutuhan yang memberi kepuasan atau mengurangi ketidakseimbangan.

Widjaja (2007:49), bahwa motivasi adalah upaya-upaya yang dilakukan merangsang pegawai untuk mau bekerja dengan kegiatan-kegiatannya. Kegiatan yang dilakukan ini berbeda antara pegawai yang satu dengan lainnya. Perbedaan ini disebabkan oleh perbedaan motif, tujuan dan kebutuhan dari masing-masing pegawai yang bekerja, juga oleh karena perbedaan waktu dan tempat.

Menurut Siagian (2004:137) yang mengutip teori Maslow dalam bukunya "Motivation and Personality" tahun 2002, bahwa motivasi merupakan satu penggerak dari dalam hati seseorang untuk melakukan atau mencapai sesuatu tujuan. Motivasi juga bisa dikatakan sebagai rencana atau keinginan untuk menuju kesuksesan dan menghindari kegagalan hidup. Dengan kata lain motivasi adalah sebuah proses untuk tercapainya suatu tujuan. Seseorang yang mempunyai motivasi berarti ia telah mempunyai kekuatan untuk memperoleh kesuksesan dalam kehidupan.

Mengingat pentingnya motivasi bagi perkembangan prestasi kerja pegawai maupun organisasi, maka dalam usaha memotivasi pegawai harus dilaksanakan secara mendalam dengan berpegangan pada sejumlah prinsip sebagai pegangan dalam bertindak. Menurut Nitisemito (2006:67), terdapat 5 (lima) prinsip-prinsip motivasi yaitu:

a. Prinsip Mengikutsertakan

Keikutsertaan pegawai dalam suatu organisasi dalam menentukan sasaran atau kebijakan dan adanya peluang untuk berpartisipasi secara aktif dalam suatu organisasi menjadi faktor pendorong bagi pegawai untuk bekerja secara lebih baik.

b. Prinsip Komunikasi 
Adanya komunikasi yang baik dan bersifat dua arah antara pegawai dengan atasan dan antara sesama pegawai akan dapat meningkatkan kualitas pekerjaan pegawai dari waktu ke waktu.

c. Prinsip Pengakuan

Adanya pengakuan yang diberikan oleh atasan kepada para pegawai yang berhasil mencapai suatu keberhasilan tertentu akan menjadi pemicu bagi pegawai untuk meningkatkan kinerja.

d. Prinsip Wewenang yang Didelegasikan Adanya pemberian tugas dan pemberian delegasi atau kepercayaan dari atasan kepada pegawai akan dapat meningkatkan kinerja pegawai karena mereka merasa diberi kepercayaan untuk menyelesaikan pekerjaan tertentu

e. Prinsip Perhatian Timbal Balik

Adanya perhatian yang diberikan oleh atasan kepada pegawai dalam menyelesaikan pekerjaan merupakan penggerak bagi pegawai untuk bekerja secara lebih baik lagi.

\section{Kinerja Pegawai}

Kinerja adalah hasil dari interaksi antara motivasi kerja, kemampuan (abilities), dan peluang (opportunities). Kinerja sebagai tingkat keberhasilan seseorang atau kelompok orang dalam melaksanakan tugas dan tanggung jawabnya serta kemampuan untuk mencapai tujuan dan standar yang telah ditetapkan. Kinerja merefleksikan kesuksesan suatu organisasi, maka dipandang penting untuk mengukur karakteristik tenaga kerjanya. Kinerja merupakan kulminasi dari tiga elemen yang saling berkaitan yakni keterampilan, upaya sifat keadaan dan kondisi eksternal. Tingkat keterampilan merupakan bahan mentah yang dibawa seseorang ke tempat kerja seperti pengalaman, kemampuan, kecakapan antar pribadi serta kecakapan teknik (Hasibuan, 2005:176).

Menurut Siagian (2008:65), kinerja pada dasarnya adalah hasil kerja seorang pegawai selama periode tertentu dibandingkan dengan kemungkinan, misalnya standar, target/sasaran atau kinerja yang telah ditentukan terlebih dahulu dan telah disepakati bersama. Menurut Handoko (2012: 23), kinerja pada dasarnya adalah apa yang dilakukan atau tidak dilakukan pegawai. Kinerja pegawai adalah yang mempengaruhi seberapa banyak mereka memberi kontribusi kepada organisasi. Perbaikan kinerja baik untuk individu maupun kelompok menjadi pusat perhatian dalam upaya meningkatkan kinerja organisasi. Kinerja merupakan setiap gerakan, perbuatan, pelaksanaan, kegiatan atau tindakan sadar yang diarahkan untuk rnencapai suatu tujuan atau target tertentu. Pengukuran kinerja pegawai dalam penelitian ini mengacu pada pendapat Hamzah (2010: 34-37), yaitu:

1. Prestasi Kerja

Prestasi kerja merupakan catatan atas hasil-hasil yang diperoleh pegawai melalui fungsi pekerjaan tertentu selama waktu tertentu.

2. Kesetiaan

Kesetiaan merupakan pengabdian seseorang untuk mematuhi apa yang telah menjadi aturan organisasi

3. Kerjasama

Sebagai makhluk sosial manusia tidak dapat dipisahkan dari organisasi dan setiap orang di dunia ini tidak dapat berdiri sendiri melakukan segala aktivitas untuk memenuhi kebutuhannya.

4. Kejujuran

Kejujuran merupakan hal utama yang dibutuhkan oleh seseorang. Kualitas sesorang dapat dilihat dari kejujurannya. Kejujuran memiliki tiga unsur, yaitu kebenaran, kebaikan dan kegunaan

5. Tanggungjawab

Maksudnya adalah pelaksanaan kegiatan harus dilakukan sesuai dengan prinsip-prinsip administrasi yang benar dan kebijakan birokrasi.

6. Ketaatan 
Merupakan wujud dari kepatuhan. Ketaatan dapat dilihat melalui besarnya tanggungjawab terhadap tugas yang diberikan

7. Prakarsa

Merupakan keinginan yang timbul dari dalam diri seseorang untuk mewujudkan sesuatu yang berguna bagi penyelesaian pekerjaan dengan sebaik-baiknya.

\section{Kerangka Pikir}

Berdasarkan uraian pada teori di atas, yang dilakukan untuk mengkaji tentang Pengaruh Kompensasi dan Motivasi Kerja terhadap Kinerja Pegawai pada PT Tunas Dwipa Matra Cabang Pramuka Bandar Lampung. Kompensasi merupakan semua bentuk imbalan yang diberikan perusahaan kepada pegawai sebagai balas jasa atas pelaksanaan tugas atau kontribusi pegawai, baik yang diberikan secara teratur maupun situasional. Sehingga dapat diartikan sebagai pemberian penghargaan yang adil dan layak terhadap para pegawai sesuai dengan sumbangan mereka untuk mencapai tujuan perusahaan. Adapun kompensasi pada penelitian ini mengacu pada pendapat Wibowo (2011:349) bahwa kompensasi pegawai terdiri dari: kompensasi langsung, dan kompensasi tidak langsung.

Motivasi kerja merupakan upayaupaya yang dilakukan guna merangsang pegawai untuk mau bekerja dengan kegiatan-kegiatannya, yang dilakukan berbeda antara pegawai dan lainnya. Adapun motivasi kerja penelitian ini didasarkan pada pendapat Nitisemito (2006:67) yang membaginya kedalam: prinsip mengikutsertakan, prinsip komunikasi, prinsip pengakuan, prinsip wewenangan yang didelegasikan dan prinsip perhatian timbal balik.

Sedangkan kinerja merupakan hasil kerja yang dicapai oleh seseorang atau sekelompok orang dalam suatu organisasi, sesuai dengan wewenang dan tanggung jawab masing-masing dalam rangka mencapai tujuan organisasi. Adapun kinerja pegawai mengacu pada teori Hamzah (2010:37) yang terdiri dari: prestasi kerja, kesetiaan, kerja sama, kejujuran, tanggungjawab, ketaatan dan prakarsa. Berdasarkan pemaparan di atas, maka dapat digambarkan kerangka pemikiran ini adalah sebagai berikut:

Gambar 1 Kerangka Pikir Penelitian

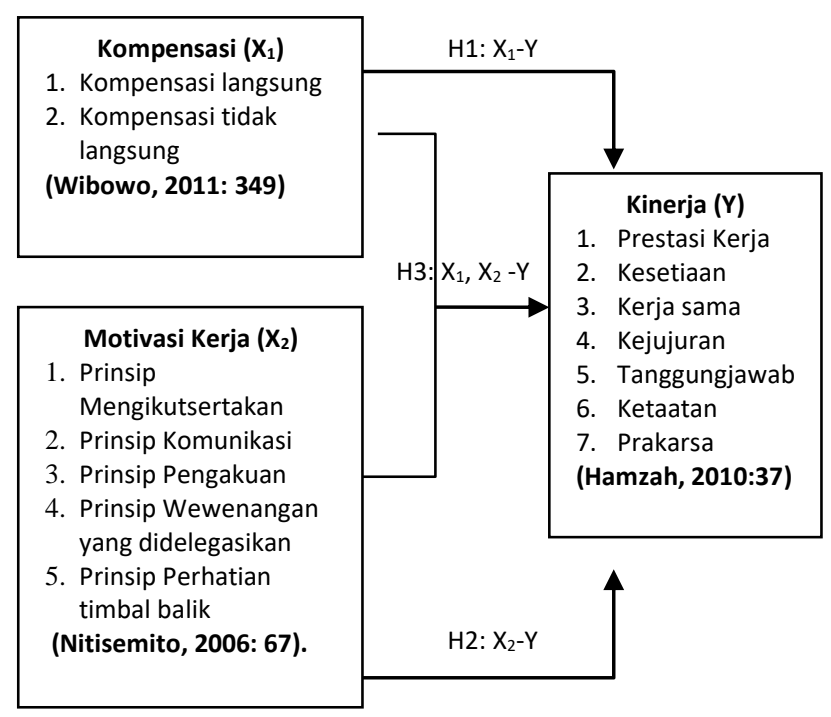

\section{Metode Penelitian}

Metode yang digunakann dalam penelitian ini adalah dengan pendekatan deskriptif asosiatif. Penelitian deskriptif adalah jenis penelitian yang menggambarkan apa yang dilakukan oleh perusahaan berdasarkan fakta-fakta yang ada untuk selanjutnya diolah menjadi data. Sedangkan asosiatif pada dasarnya untuk menguji teori dengan menggunakan hipotesis.

Populasi penelitian ini adalah seluruh pegawai PT Tunas Dwipa Matra Cabang Pramuka yang terdiri dari pegawai administrasi, sales counter, marketing dan mekanik yang seluruhnya berjumlah 229 karena penulis tidak ikut diteliti maka jumlah populasi seluruhnya adalah 228 . Jumlah sampel ditentukan berdasarkan proporsi sampel menurut Arikunto (2010) bahwa apabila objek penelitian $>100$ maka dapat diambil 10\%-25\%. Jadi sampel penelitian ini adalah $25 \%$ dari 228 orang yaitu 57 orang responden. Teknik sampling 
yang digunakan adalah Simple Random Sampling untuk memberikan kesempatan yang sama dari seluruh populasi menjadi sampel penelitian. Berdasarkan pengertian di atas maka definisi operasional dalam penelitian ini adalah Kompensasi $\left(\mathrm{X}_{1}\right)$, motivasi $\left(\mathrm{X}_{2}\right)$ Kinerja Pegawai (Variabel Y) dan kinerja (Y)

\section{Teknik Analisis Data}

Teknik analisis data penelitian ini adalah analisis kualitatif dan analisis kuantitatif. Analisis kualitatif dilakukan dengan menyederhanakan data ke dalam bentuk yang lebih mudah dibaca dan diinterpretasikan melalui pendekatan teori, kemudian dideskripsikan atau dijelaskan. Analisis statistik deskriptif. Adapun analisis kuantitatif dilakukan untuk mengetahui pengaruh kompensasi dan motivasi kerja terhadap kinerja pegawai pada PT Tunas Dwipa Matra Cabang Pramuka Bandar Lampung menggunakan analisis data regresi linier berganda, dengan bantuan program software SPSS.

\section{Hasil Penelitian}

Hasil secara deskriptif diperoleh jawaban dari responden tentang kompensasi Karyawan PT Tunas Dwipa Matra Cabang Pramuka Bandar Lampung Bandar Lampung, terdistribusi sebanyak 2 responden (4\%) memiliki kompensasi sangat baik, sebanyak 12 responden $(19 \%)$ memiliki kompensasi yang tergolong baik, sebanyak 34 responden $(60 \%)$ memiliki kompensasi cukup baik, sebanyak 10 (17\%) responden memiliki kompensasi kurang baik dan tidak ada responden yang beranggapan bahwa kompensasi sangat tidak baik. Berdasarkan hasil tersebut maka dapat dijelaskan bahwa secara umum kompensasi Karyawan PT Tunas Dwipa Matra Cabang Pramuka Bandar Lampung Bandar Lampung tergolong cukup baik. Hal tersebut berarti pegawai Karyawan PT Tunas Dwipa Matra Cabang Pramuka Bandar Lampung Bandar Lampung dapat dapat berkompensasi dalam menciptakan kinerja pegawai
Pada variabel Kompensasi berdasar indikator, yaitu sebagian besar jawaban responden adalah masuk dalam kategori baik. Indikator dominan pada variable kompensasi adalah pada indikator konsep diri dengan nilai rata-rata persen adalah sebesar 68,5\% (baik), sedangkan indikator jawaban responden adalah pada indikator kompensasi tidak langsung yaitu sebesar 67,6\% (cukup baik).

Deskripsi responden tentang motivasi kerja PT Tunas Dwipa Matra Cabang Pramuka Bandar Lampung Bandar Lampung, terdistribusi sebanyak 14 responden $(25 \%)$ menyatakan penempatan tergolong baik, sebanyak 27 responden (47\%) menyatakan penempatan cukup baik, sebanyak 11 (19\%) responden menyatakan penempatan kurang baik dan sebanyak 5 (9\%) responden menyatakan penempatan sangat tidak baik. Secara umum motivasi kerja PT Tunas Dwipa Matra Cabang Pramuka Bandar Lampung Bandar Lampung tergolong cukup baik. Hal tersebut berarti pegawai Karyawan PT Tunas Dwipa Matra Cabang Pramuka Bandar Lampung Bandar Lampung telah sesuai dalam menempatkan pegawainya untuk menciptakan kinerja pegawai.

Berdasarkan hasil jawaban responden pada masing-masing pernyataan yang diajukan, maka didapatkan kategori jawaban responden pada variabel motivasi kerja berdasar indikator, yaitu sebagian besar jawaban responden adalah masuk dalam kategori cukup baik. Sedangkan indikator dominan pada variabel motivasi kerja adalah pada indikator mengikutsertakan dengan nilai rata-rata persen adalah sebesar 70,2\% (baik), sedangkan indikator terendah jawaban responden adalah pada indikator pengakuan yaitu sebesar 61,6\% (cukup baik).

Deskripsi kinerja Karyawan PT Tunas Dwipa Matra Cabang Pramuka Bandar Lampung Bandar Lampung, terdistribusi sebanyak 5 responden (9\%) memiliki kinerja yang sangat baik, sebanyak 20 responden $(35 \%)$ memiliki kinerja yang 
baik, sebanyak 23 responden (40\%) memiliki kinerja yang cukup baik, sebanyak 9 responden (16\%) responden memiliki kinerja yang kurang baik dan tidak ada responden yang memiliki kinerja tidak baik. Berdasarkan hasil tersebut maka dapat dijelaskan bahwa secara umum kinerja Karyawan PT Tunas Dwipa Matra Cabang Pramuka Bandar Lampung Bandar Lampung tergolong baik. Hal tersebut berarti pegawai Karyawan PT Tunas Dwipa Matra Cabang Pramuka Bandar Lampung Bandar Lampung telah melakukan kerja sesuai dengan waktu yang telah ditentukan. Berdasarkan hasil jawaban responden pada masing-masing pernyataan yang diajukan, maka didapatkan kategori jawaban responden pada variabel kinerja berdasar indikator, yaitu sebagian besar jawaban responden adalah masuk dalam kategori cukup baik. Sedangkan indikator dominan pada variabel kinerja adalah pada indikator prakarsa dengan nilai rata-rata persen adalah sebesar $71,9 \%$ (cukup baik), sedangkan indikator terendah jawaban responden adalah pada indikator kerjasama yaitu sebesar $60,7 \%$ (cukup baik)

Hasil perhitungan regresi pada tabel coefficient di atas diperoleh persamaan regresi linier berganda antara variabel kompensasi, motivasi kerja dan kinerja adalah:

\section{$\mathrm{Y}=\mathbf{6 , 3 9 +} 0,289 \mathrm{X}_{\mathbf{1}}+\mathbf{0 , 5 0 7} \mathrm{X}_{\mathbf{2}}$}

a. Nilai konstanta sebesar $(a=6,39)$ mempunyai makna bahwa jika tidak terdapat perubahan pada faktor dari variabel bebas yang meliputi kompensasi dan motivasi kerja, maka kinerja pegawai dianggap konstan sebesar 6,39 menunjukkan nilai konstanta yang positif, artinya apabila kompensasi dikembangkan dengan baik, motivasi kerja meningkat maka kinerja akan tetap (konstan) memiliki nilai sebesar 6,39 satuan.

b. Nilai koefisien regresi (b) $\mathrm{X}_{1}$ adalah sebesar 0,289, mengandung arti jika kompensasi ditingkatkan 1 satuan maka akan meningkatkan nilai kinerja sebesar 0,289 satuan.

c. Nilai koefisien regresi (b) $\mathrm{X}_{2}$ adalah sebesar 0,507, mengandung arti jika motivasi kerja ditingkatkan 1 satuan maka akan meningkatkan nilai kinerja sebesar 0,507 satuan.

Berdasarkan hasil tersebut maka dapat disimpulkan bahwa kontribusi dan pengaruh motivasi kerja $\left(\mathrm{X}_{2}\right)$ terhadap kinerja (Y) pegawai lebih dominan dari pada pengaruh kompensasi $\left(\mathrm{X}_{1}\right)$ pegawai terhadap kinerja Karyawan PT Tunas Dwipa Matra Cabang Pramuka Bandar Lampung Bandar Lampu.

Besarnya nilai pengaruh kompensasi dan motivasi kerja secara bersama-sama terhadap kinerja ditunjukkan oleh nilai $\mathrm{R}^{2}$ (R Square) yaitu 0.627 atau $62.7 \%$. Pengaruh tersebut bernilai positif, artinya kinerja dipengaruhi secara bersama-sama oleh kompensasi dan motivasi kerja dengan nilai sebesar $62,7 \%$. Sementara itu sisanya sebesar $38,3 \%$ tidak dipengaruhi oleh kompensasi dan motivasi kerja tetapi dapat dipengaruhi oleh berbagai variabel lain yang tidak dibahas dalam penelitian

Hasil pengujian hipotesis yang dilakukan secara simultan untuk mengetahui pengaruh secara bersama-sama antara kompensasi dan motivasi kerja terhadap kinerja Karyawan PT Tunas Dwipa Matra Cabang Pramuka Bandar Lampung Bandar Lampung karena diperoleh $\mathrm{F}_{\text {hit }} 45,46$ dan $\mathrm{F}_{\text {tab }}$ pada $\mathrm{DF}_{1}=2$, DF2 $=54$ dan taraf signifikan $5 \%(\alpha=0,05)$ adalah 3.15 .

Dengan demikian maka perbandingan $F_{\text {hitung }}$ dengan $F_{\text {tabel }}$ pada taraf signifikan $5 \%$, adalah 45,46> 3.15. Berdasarkan perbandingan tersebut maka diketahui bahwa $F_{\text {hitung }}$ lebih besar dari $F_{\text {tabel }}$ pada taraf signifikan $5 \%(\alpha=0,05)$ dan uji signifikansi menghasilan nilai sig. $=0,000<0,05$. Dengan demikian maka Ha diterima, artinya kompensasi dan motivasi kerja secara bersama-sama berpengaruh secara signifikan terhadap kinerja Karyawan PT Tunas Dwipa Matra Cabang Pramuka Bandar Lampung Bandar 


\section{Lampung}

Didapatkan nilai thitung pada variable kompensasi $\left(\mathrm{X}_{1}\right)$ adalah sebesar 2.579, nilai $t_{\text {hitung }}$ dan $t_{\text {tabel }}$ pada taraf signifikan 95\% $(\alpha=0,05)$ adalah 1.671. Berdasarkan perbandingan tersebut maka nilai $t_{\text {hitung }}$ pada variabel kompensasi adalah lebih besar daripada nilai $t_{\text {tabel, }}$, dan dengan taraf signifikan yaitu nilai sig. $X_{1}=0,015<0,05$. Dari tabel di atas, didapatkan nilai thitung pada variable motivasi kerja $\left(\mathrm{X}_{2}\right)$ adalah sebesar 6.347, nilai $t_{\text {hitung }}$ dan $t_{\text {tabel }}$ pada taraf signifikan $95 \%(\alpha=0,05)$ adalah 1.671 (Lihat Lampiran 7). Berdasarkan perbandingan tersebut maka nilai thitung pada motivasi kerja adalah lebih besar daripada nilai $t_{\text {tabel, }}$ dan dengan taraf signifikan yaitu nilai sig. $\mathrm{X}_{1}=0,000<0,05$. Sesuai dengan hasil penelitian di atas yang dilakukan dengan analisis kuantitatif.

\section{Interpretasi}

Hasil penelitian menunjukkan bahwa kompensasi berpengaruh positif dan signifikan terhadap kinerja Karyawan PT Tunas Dwipa Matra Cabang Pramuka Bandar Lampung Bandar Lampung. Kompensasi di Karyawan PT Tunas Dwipa Matra Cabang Pramuka Bandar Lampung Bandar Lampung secara umum cenderung dalam kategori yang baik dimana sebagian besar pegawai menyatakan bahwa kompensasi termasuk dalam kategori baik. Sedangkan pengukuran tentang kompensasi perindikator juga menunjukkan hal serupa. Penjelasan dan hasil perhitungan di atas sejalan dengan teori yang dikemukakan oleh (Gibson, 1996:82) yang menyatakan bahwa beberapa hal yang terkait dengan tercapainya kinerja diantaranya adalah kompensasi. Efektivitas pegawai sebagian besar ditentukan oleh kompensasi.

Faktor lain yang mempengaruhi kinerja adalah motivasi kerja, secara umum berdasarkan hasil analisis kualitatif motivasi kerja PT Tunas Dwipa Matra Cabang Pramuka Bandar Lampung Bandar Lampung tergolong dalam kategori baik. Hasil penelitian menunjukkan bahwa
Karyawan PT Tunas Dwipa Matra Cabang Pramuka Bandar Lampung Bandar Lampung memahami penempatan karyawan berkaitan dengan kemampuan sumber daya manusia (aparatur) dalam menggali dan mengolah potensi secara optimal.

Perilaku manusia itu pada hakekatnya adalah berorientasi pada tujuan dengan kata lain bahwa perilaku seseorang itu pada umumnya dirangsang oleh keinginan untuk mencapai beberapa tujuan. Upaya perbaikannya dapat dilakukan melalui perbaikan motivasi kerja. Birokrasi pemerintah pada dasarnya dibentuk untuk mengaktualisasikan tugas pemerintah dalam memberikan dan memenuhi kebutuhan layanan sipil, sehingga birokrasi mempunyai kewajiban untuk menjadi pelayan bagi kepentingan masyarakat.

Hasil penelitian ini sejalan dengan teori yang menjelaskan bahwa kinerja pada dasarnya merupakan hasil kerja secara kualitas dan kuantitas yang dicapai seorang pegawai dalam melaksanakan tugasnya sesuai tanggung jawab yang diberikan kepadanya. Dalam hal ini, pegawai bisa belajar seberapa besar kinerja mereka melalui sarana informasi seperti komentar baik dari mitra kerja.

Begitu pentingnya masalah kinerja pegawai ini, sehingga tidak salah bila inti pengelolaan sumber daya manusia adalah bagaimana mengelola kinerja SDM. Mengelola manusia dalam konteks organisasi berarti mengelola manusia agar dapat menghasilkan kinerja yang optimal bagi organisasi. Oleh karenanya kinerja pegawai ini perlu dikelola secara baik untuk mencapai tujuan organisasi, sehingga menjadi suatu konsep manajemen kinerja (performance management).

Menurut definisinya, manajemen kinerja adalah suatu proses strategis dan terpadu yang menunjang keberhasilan organisasi melalui pengembangan performansi SDM. Dalam manajemen kinerja kemampuan SDM sebagai kontributor individu dan bagian dari kelompok dikembangkan melalui proses 
bersama antara manajer dan individu yang lebih berdasarkan kesepakatan daripada instruksi. Kesepakatan ini meliputi tujuan (objectives), persyaratan pengetahuan, keterampilan dan kemampuan, serta pengembangan kinerja dan perencanaan pengembangan pribadi.

Manajemen kinerja bertujuan untuk dapat memperkuat budaya yang berorientasi pada kinerja melalui pengembangan keterampilan, kemampuan dan potensi-potensi yang dimiliki oleh SDM. Sifatnya yang interaktif ini akan meningkatkan motivasi dan memberdayakan SDM dan membentuk suatu kerangka kerja dalam pengembangan kinerja. Manajemen kinerja juga dapat menggalang partisipasi aktif setiap anggota organisasi untuk mencapai sasaran organisasi melalui penjabaran sasaran individu maupun kelompok sekaligus mengembangkan protensinya agar dapat mencapai sasarannya itu. Berdasarkan tugasnya ini, manajemen kinerja dapat dijadikan landasan bagi promosi, mutasi dan evaluasi, sekaligus penentuan kompensasi dan penyusunan program pelatihan. Manajemen kinerja juga dapat dijadikan umpan balik untuk pengembangan karier dan pengembang an pribadi SDM.

Keunggulan manajemen kinerja adalah penentuan sasaran yang jelas dan terarah. Di dalamnya terdapat dukungan, bimbingan, dan umpan balik agar tercipta peluang terbaik untuk meraih sasaran yang menyertai peningkatan komunikasi antara atasan dan bawahan. Untuk dapat menerapkan manajemen kinerja dalam suatu organisasi, diperlukan adanya prasyarat dasar yang harus dipenuhi dalam suatu organisasi, yaitu adanya suatu indikator kinerja (key performance indicator) yang terukur secara kuantitatif dan jelas batas waktunya. Ukuran ini harus dapat menjawab berbagai permasalahan yang dihadapi oleh organisasi tersebut.

Semua ukuran kinerja tersebut biasanya dituangkan dalam suatu bentuk kesepakatan antara atasan dan bawahan yang sering disebut sebagai suatu kontrak kinerja (performance contract). Dengan adanya kontrak kinerja, maka atasan bisa menilai apakah si bawahan sudah mencapai kinerja yang diinginkan atau belum. Kontrak kinerja ini berisikan suatu kesepakatan antara atasan dan bawahan mengenai indikator kinerja yang ingin dicapai, baik mengenai sasaran pencapaiannya maupun jangka waktu pencapaiannya. Ada dua hal yang perlu dicantumkan dalam kontrak kinerja yaitu sasaran akhir yang ingin dicapai (lag) serta program kerja untuk mencapainya (lead). Keduanya perlu dicantumkan supaya pada saat evaluasi nanti berbagai pihak bersikap secara fair, dan tidak melihat hasil akhir semata, namun juga proses kerjanya, dapat saja seorang bawahan belum mencapai semua hasil kerja yang ditargetkan, tetapi dia sudah melaksanakan semua program kerja yang sudah digariskan, tentu saja atasan tetap harus memberikan reward untuk dedikasinya, walaupun sasaran akhir belum tercapai. Hal ini juga bisa menjadi dasar untuk perbaikan di masa mendatang (continuous improvement)

Adanya suatu sistem reward and punishment yang bersifat konstruktif dan konsisten dijalankan. Konsep reward ini tidak selalu harus bersifat finansial, tetapi bisa juga berupa bentuk lain seperti promosi, kesempatan pendidikan dan lainlain. Reward and punishment diberikan setelah melihat hasil realisasi kinerja, apakah sesuai dengan indikator kinerja yang telah direncanakan atau belum. Tentu saja harus ada suatu performance appraisal atau penilaian kinerja lebih dahulu sebelum reward and punishment. Penerapan punishment ini harus hati-hati, karena dalam banyak hal pembinaan jauh lebih bermanfaat.

Menerapkan konsep manajemen SDM berbasis kompensasi. Umumnya organisasi yang berkinerja tinggi memiliki kamus kompensasi dan menerapkan kompensasi itu tersebut kepada hal-hal yang penting, seperti manajemen kinerja, rekruitmen, seleksi, pendidikan, pengembangan 
pegawai, dan promosi. Kompensasi ini meliputi kompensasi inti organisasi, kompensasi perilaku, dan kompensasi teknis yang spesifik dalam pekerjaan. Jika kompensasi ini sudah dibakukan dalam organisasi, maka kegiatan manajemen SDM akan menjadi lebih transparan, dan pimpinan organisasi juga dengan mudah mengetahui kompensasi apa saja yang perlu diperbaiki untuk membawa organisasi menjadi berkinerja tinggi.

Adapun keterkaitan dantara motivasi kerja dengan kinerja sangat erat. Tujuan motivasi kerja adalah mencocokkan antara karakteristik individu (pengetahuan, ketrampilan, pengalaman, dan lain-lain) dengan persyaratan jabatan yang harus dimiliki individu tersebut dalam memegang suatu jabatan. Kegagalan dalam mencocokkan kedua hal tersebut dapat menyebabkan kinerja karyawan tidak optimal dan kepuasan kerja sangat rendah, sehingga tidak jarang hal ini membuat individu dan organisasi menjadi frustrasi. Dalam usaha mencari individu yang tepat dan sesuai untuk jabatan tertentu maka pihak manajemen harus melakukan pengukuran (assessment) terhadap tuntutan-tuntutan (demands) dan persyaratan-persyaratan (requirements) dari jabatan tersebut.

Untuk mendukung motivasi kerja perlu dilakukan analisis jabatan dalam sebuah perusahaan. Hasil analisis jabatan akan menghasilkan uraian pekerjaan atau jabatan dan persyaratan pekerjaan atau jabatan yang dapat digunakan dalam motivasi kerja. Analisis jabatan sangat berperan sekali dalam motivasi kerja. Dengan adanya analisis jabatan akan menghasilkan pegawai yang mampu bekerja efektif dan efisien dalam mencapai tujuan perusahaan sehingga sesuai dengan kebutuhan perusahaan baik kualitas maupun kuantitas.

Motivasi kerja harus berpegang kepada prinsip "The right man on the right place and the right man on the right job"yang artinya penempatan orang-orang yang tepat pada tempat dan untuk jabatan yang tepat. Dengan melakukan motivasi kerja yang sesuai dengan prinsip tersebut di atas diharapkan akan meningkatkan kinerja pegawai sehingga tujuan perusahaan dapat tercapai. Dengan analisis jabatan ini akan diperoleh informasi tentang segala sesuatu yang berkaitan dengan suatu jabatan. Informasi ini dapat dijadikan dasar yang kuat bagi pengambil keputusan-keputusan yang berkaitan dengan sumber daya manusia. Dimana analisis jabatan ini akan dijadikan dasar dalam motivasi kerja.

Analisis jabatan merupakan hal mendasar dalam proses pengembangan sumber daya manusia. Tanpa adanya data yang akurat tentang profil dari masingmasing jabatan, jenis-jenis kemampuan dan keterampilan yang dibutuhkan, serta pengalaman dan pendidikan yang dipersyaratkan untuk menduduki jabatan tersebut, maka proses pengembangan sumber daya manusia akan menjadi sulit. Motivasi kerja akan timpang karena tidak diimbangi informasi yang memadai dan akurat, pengembangan dan pelatihan mungkin tidak dapat mencapai tujuan, begitu juga halnya dengan manajemen penilaian kinerja.

\section{Kesimpulan}

1. Deskripsi kompensasi $\left(\mathrm{X}_{1}\right)$ pegawai diketahui bahwa konsep diri pegawai sudah baik, sedangkan indikator pengetahuan perlu ditingkatkan. Pada variabel motivasi kerja $\left(\mathrm{X}_{2}\right)$ secara umum sudah baik terutama pada indikator keterampilan, sedangkan indikator pengalaman perlu mendapatkan perhatian. Kinerja pegawai yang paling menonjol adalah kerjasama sedangkan komitmen pegawai perlu diupayakan meningkat.

2. Ada pengaruh positif kompensasi $\left(\mathrm{X}_{1}\right)$ terhadap kinerja Karyawan PT Tunas Dwipa Matra Cabang Pramuka Bandar Lampung Bandar Lampung. Hasil ini menunjukkan bahwa jika kompensasi pegawai baik dapat meningkatkan kinerja pegawai. Artinya semakin 
kompetitif pegawai akan membuat kinerja semakin baik. Standar kompensasi dapat memberikan keuntungan lebih bagi organisasi dan pegawai dalam meningatkan kinerjanya.

3. Ada pengaruh positif motivasi kerja $\left(\mathrm{X}_{2}\right)$ terhadap kinerja Karyawan PT Tunas Dwipa Matra Cabang Pramuka Bandar Lampung Bandar Lampung. Hasil ini menunjukan bahwa untuk meningkatkan kinerja dapat dilakukan dengan melakukan penempatan PNS dengan baik sesuai latar belakang pendidikan, keterampilan dan sebagainya sehingga pekerjaan dapat dlaksanakan dengan senang dan nyaman.

4. Ada pengaruh positif kompensasi $\left(\mathrm{X}_{1}\right)$ dan motivasi kerja $\left(\mathrm{X}_{2}\right)$ secara bersama sama terhadap kinerja Karyawan PT Tunas Dwipa Matra Cabang Pramuka Bandar Lampung Bandar Lampung. Hasil ini menunjukan bahwa untuk meningkatkan kinerja dapat dilakukan dengan meningkatkan kompensasi pegawai dan melakukan motivasi kerja dengan baik sesuai latar belakang pendidikan, keterampilan dan sebagainya sehingga pekerjaan dapat dlaksanakan dengan senang dan nyaman.

\section{Implikasi}

Berdasarkan kesimpulan yang telah dikemukakan di atas, maka diajukan beberapa saran sehubungan dengan upaya meningkatkan kinerja Karyawan PT Tunas Dwipa Matra Cabang Pramuka Bandar Lampung Bandar Lampung. Saran-saran tersebut dapat dikemukakan sebagai berikut:

1. Kepada pimpinan di lingkungan Karyawan meningkatkan pengetahuan pegawai, sehingga dapat membentuk keterampilan yang mendukung pekerjaannya, pendekatan personal dilakukan oleh atasan kepada bawahan atau antar sesama rekan kerja, supaya meningkatkan kompensasi pegawai sehingga pegawai terdorong untuk bekerja lebih optimal.

2. Mempertimbangkan faktor akademis, sikap, kemampuan, pengalaman untuk menemukan orang cocok untuk menempati bidang jabatan tertentu melalui analisis jabatan yang akurat dan independen agar penempatan tugas bagi pegawai pada suatu jabatan sudah memperhatikan syarat-syarat jabatan yang ada berdasarkan standar kompensasi dan keterampilannya.

3. Pegawai bagian administrasi disarankan untuk meningkatkan kinerja secara lebih maksimal, khususnya komitmen dalam menyelesaikan pekerjaan secara tepat waktu dan tepat sasaran, serta bekerja sesuai dengan standar operasional prosedur yang telah ditetapkan sesuai dengan tugas pokok dan fungsi masingmasing pegawai

\section{Daftar Pustaka}

Arikunto, Suharsimi. 2010. Prosedur Penelitian: Suatu Pendekatan Praktek. Edisi Revisi VI. Rineka Cipta. Jakarta.

Handoko, T. Hani. 2012. Manajemen Personalia dan Sumber Daya Manusia. BPFE. Yogyakarta.

Hasibuan, Malayu SP. 2005. Manajemen Sumber Daya Manusia. Edisi Revisi. Bumi Aksara. Jakarta.

Hamzah B, Uno. 2010. Teori Motivasi dan Pengukurannya: Analisis di Bidang Pendidikan. Bumi Aksara. Jakarta.

Hita, Yoti Gama. 2013. Pengaruh Kompensasi dan Disiplin Kerja terhadap Kinerja Karyawan dengan Motivasi Sebagai Intervening Variabel pada Perum Perhutani Unit 1 Jawa Tengah. Fakultas Ekonomi dan Bisnis. Universitas Indonesia. Depok. 
Lufitasari, Resti. 2014. Pengaruh Motivasi Kerja, Disiplin Kerja dan Kompensasi terhadap Kinerja pegawai pada Dinas Pendapatan, Pengelolaan Keuangan dan Aset D.I. Yogyakarta. Fakultas Ekonomi Universitas Negeri Yogyakarta.

Masri, Singarimbun dan Effendy, Sofyan. 2007. Metode Penelitian Survey. Edisi Revisi. Penerbit LP3ES. Jakarta

Moenir. 2006. Manajemen Pelayanan Umum di Indonesia. PT Bumi Aksara. Jakarta.

Nitisemito, Alex, S., 2006. Manajemen Personalia (Manajemen Sumber Daya Manusia), Ghalia Indonesia, Jakarta.

Sarwoto, Edy. 2006. Disiplin, Teori dan Praktik. Pustaka Ilmu. Surabaya.

Sedarmayanti. 2013. Manajemen Kualitas Pelayanan Publik. Gramedia Pustaka Utama. Jakarta.

Setyani, Tri Budi. 2014. Analisis Pengaruh Kompensasi, Motivasi, Lingkungan Kerja, dan Budaya Organisasi terhadap Kinerja Karyawan di Lingkungan Pegawai Kantor PDAM Boyolali. Fakultas Ekonomi dan
Bisnis. Universitas Muhammadiyah. Surakarta.

Siagian, Sondang P. 2008. Manajemen Sumber Daya Manusia. (Cetakan 15). Bumi Aksara..Jakarta.

Siagian, Sondang P. 2004. Manajemen Terapan dalam Organisasi. Rajawali Press. Jakarta.

Siswanto, Bedjo. 2006. Perspektif Perilaku Birokrasi: Dimensi-Dimensi Prima Ilmu Administrasi Negara Jilid II. Rajawali. Jakarta.

Sugiyono, 2005. Metode Penelitian Bisnis. Alfabeta Jakarta

Tohardi, Ahmad. 2007. Pemahaman Praktis Manajemen Sumber Daya Manusia. Mandar Maju. Bandung.

Husein, Umar. 2007. Metode Penelitian Untuk Skripsi dan Tesis Bisnis. Raja Grafindo Persada. Jakarta.

Wibowo, Handitya. 2011. Optimalisasi Kedisiplinan Kerja. Bina Ilmu. Semarang.

Widjaja, AW. 2007. Manajemen Sumber Daya Manusia. BPFE UGM. Yogyakarta. 